\title{
Проект В.А. Ирмана по переименованию объектов Владивостокской крепости как попытка русификации Дальнего Востока
}

В июне 1910 г. комендант Владивостокской крепости В.А. Ирман отправил на имя главного руководителя работ по усилению Владивостокской крепости инженер-генералу А.П. Вернандеру доклад, содержавший предложение о переименовании объектов Владивостокской крепости (РГВИА. Ф. 802. Оп. 5. Д. 16793. Л. 383-385) ${ }^{1}$. В отличие от иных документов, поступавших на рассмотрение Александру Петровичу Вернандеру, доклад Ирмана касался не вопросов материально-технического характера, связанных с строительством Владивостокской крепости, а затрагивал момент идеологического характера. Предложение коменданта крепости было попыткой использовать Владивостокскую крепость в рамках внутренней политики Российской империи как своеобразный символ имперской власти на берегах Тихого океана. Инициатива Ирмана предлагала русифицировать Дальний Восток при помощи переименований объектов крепости в державно-патриотическом духе.

Данный проект, если рассматривать его в контексте усилий центральных и региональных властей по сохранению Дальнего Востока, как представляется, способен пролить свет на те представления о месте Владивостокской крепости во внутренней политике Российской империи после Русско-японской войны и методики символического закрепления власти на окраинах империи, благодаря которым Санкт-Петербург и подчинённые ему местные военные и гражданские администраторы, собирались окончательно "присоединить" отдалённый регион к основному имперскому телу.

Сообразно этой цели исследовательские задачи данной работы представляется возможным сформулировать следующим образом: 1) каковы были мнения о необходимости существования Владивостокской крепости? 2) каковы были взгляды высшего руководства Российской империи и дальневосточной администрации на регион? 3) насколько проект В.А. Ирмана по переименованию объектов Владивостокской крепости укладывался в общее русло политики на Дальнем Востоке и каких целей собирались добиться при его реализации?

Намерение использовать крепость в идеологическом аспекте напрямую зависело от отношения центральной власти к дальневосточному региону. Тем более что это отношение неоднократно менялось. Эти изменения описаны в ряде работ, например, монографии омского исследователя А.В. Ремнёва, который делит его на несколько разных этапов. Изначально Дальний Восток нужен был России в качестве двух военно-экономических плацдармов для дальнейшего расширения: Охотско-Камчатский край - для Северной Америки; Приамурский край - для Маньчжурии [8, с. 14-15]. После продажи Аляски, начала активной имперской экспансии в Средней Азии среди элит и русской общественности стало господствовать мнение о Дальнем Востоке, как о бесплодной, пустынной и не особо нужной окраине [8, с. 200-201]. Интерес к региону вернулся на рубеже XIX-XX вв., когда для России были одновременно характерны развитие экономических связей России с странами азиатского региона, активная внешняя политика на южном и восточном направлениях, повышение общественного интереса к региону в целом, вызванное проникно-

1 РГВИА - Российский государственный военно-исторический архив.

(C) Азаревич B. K., 2021

АЗАРЕВИЧ Василий Кириллович, экскурсовод Государственного музея-заповедника "Владивостокская крепость" (е. Владивосток). E-mail: v.k.azarevich@gmail.com 
вением культуры дальневосточных стран в повседневную жизнь [8, с. 319]. Наиболее удачным решением вопроса перенаселения плодоносных земель европейской части России стало видеться переселение крестьян на Дальний Восток [8, с. 320]. Российская империя развернулась к этому региону, сфрормировав самые разнообразные планы по освоению региона и экспансии в страны Азии, но все они были пресечены поражением в Русско-японской войне.

После поражения в Русско-японской войне руководство страны и региона стало исходить из представления о том, что Дальний Восток будет передним краем обороны России от опасностей, исходящих из Азии, а первоочередной задачей власти становится превращение данного региона в как можно более русский, чтобы он уже никогда не мог быть потерян с такой лёгкостью, как Аляска или Порт-Артур [8, с. 441]. Теперь речь шла о сохранении уже имеющихся дальневосточных рубежей, а не об их расширении вглубь Азии.

Проект Ирмана был одним из событий, в структуре российской внутренней политики на Дальнем Востоке. Структуры, как правило, состоят из различных государственных институтов, которые могут действовать друг на друга или стараться сохранить свою независимость. Владимир Ирман в рамках одной структуры представлял сразу несколько институтов: армию, местную администрацию и имперскую власть. При этом он взаимодействовал с другими государственными институтами в лице Приамурского генерал-губернатора, руководства армии и отдельных имперских ведомств. Поэтому, чтобы лучше понять суть проекта Ирмана, стоит рассмотреть, что на разных уровнях власти (общеимперском, региональном) думали о Владивостокской крепости и Дальнем Востоке царские чиновники. Для лучшего представления об этих замыслах стоит рассмотреть систему взглядов тогдашней русской элиты, начиная с сановников в Петербурге.

После Русско-японской войны и заключения Портсмутского мира отношение к Дальнему Востоку поменялось на тревожно-оборонительное, согласно которому этот регион надо было сберечь и сохранить как последний рубеж России на востоке. Эти настроения были характерны как для высших гражданских, так и для военных чиновников. Однако по тому, как именно сберегать Дальний Восток, существовали разные точки зрения.

Комиссия по вооружению Владивостокской крепости под руководством Начальника Владивостокской крепостной артиллерии генерал-лейтенанта В.Ф. Белого действовала на протяжении 1906-1908 гг. [1, с. 35]. Результаты работы комиссии были представлены в Главном управлении Генерального штаба военным инженером генерал-лейтенантом Вернандером, занимавшим тогда пост товарища (заместителя) генерал-инспектора по инженерной части, вместе с его проектом по усилению Владивостокской крепости. Данный план был представлен на заседании Совета государственной обороны, где по его поводу разгорелась оживлённая дискуссия: в условиях, когда большинство членов Совета считали, что война с Японией в ближайшем будущем невозможна, а усиление Владивостока стоит производить постепенно, на повестку дня были выдвинуты следующие варианты развития крепости: а) Крепость Владивосток предназначена оборонять Владивостокскую бухту; б) крепость Владивосток, как единственный укреплённый пункт Уссурийского края, должна держать на себе оборону региона до тех пор, пока не подоспеют подкрепления; в) во Владивостоке должны остаться лишь береговые батареи, крепость надо ликвидировать и в защите города основной упор делать на береговые мины; г) крепость Владивосток должна защищать город от фрлота противника с моря и овладения им с суши [1, с. 38-39].

Характерно, что на обсуждении данного проекта резко против усиления Владивостокской крепости выступил действующий военный министр империи А.Ф. Редигер, считавший, что в случае войны необходимо организовать линию сухопутной обороны в районе Имана (Дальнереченска), а сам Владивосток требуется оставить [6, с. 151-152]. Война с Японией в ближайшее время невозможна, а без привязки Приморья к России при помощи Амурской железной дороги, считал Редигер, защита Владивостока представляет проигрышным и бессмысленным делом [6, с. 150]. Ближайшей задачей России Редигер считал пятьдесят лет мира с Японией, за время которых Россия должна была заселить Дальний Восток [6, с. 150]. Редигер был единственным, кто проголосовал против проекта усиления Владивостокской крепости. Черту в 
дискуссии подвёл Николай II, вынесший резолюцию "Упразднять Владивостокскую крепость не признаю возможным и не вижу в этом надобности в виду современного политического положения на Дальнем Востоке. Крепость должна быть постепенно приведена в такое состояние, которое она будет иметь со временем, по окончанию постройки Амурской железной дороги"[1, с. 41].

Данная дискуссия обнажила факт существования в имперских верхах двух партий, чьи взгляды на Дальний Восток и его значение для России заметно отличались. Одну из этих партий А.В. Ремнёв называет "железнодорожниками", а другую "фолотской" [8, с. 441-442]. Согласно представлениям "железнодорожной" партии, в ближайшем будущем война между Россией и Японией не представлялась возможной, основной упор в освоении Дальнего Востока было необходимо сделать на развитие сети железнодорожных магистралей, связывающих регион с остальной Россией, а вместо армии принадлежность этой окраины к Российской империи должны были закрепить мирные колонисты. Представители "фрлотской" партии считали необходимым возрождение Тихоокеанского фрлота, как единственной силы, способной защитить рубежи Дальнего Востока. Согласно воспоминаниям министра финнансов Российской империи В.Н. Коковцова, к сторонникам сохранения и укрепления Владивостокской крепости принадлежали сам Коковцов, П.А. Столыпин, морской министр и министр иностранных дел [4, с. 359].

Обе партии считали, что война с Японией в ближайшее время невозможна, приамурский генерал-губернатор П.Ф. Унтербергер придерживался иных взглядов. Он считал, что Япония готовится к скорой войне с Россией, и слал соответствующие телеграммы главе правительства и военному министру. Благодаря им вопрос усиления Владивостокской крепости опять вышел на повестку дня Совета Государственной обороны, а на П.А. Столыпина эти телеграммы "произвели очень сильное впечатление" [4, с. 361]. На одном из совещаний правительства, в присутствии императора, заново поднялся вопрос о телеграммах Унтербергера и о том, насколько они соответствуют реальности. Мнения снова разделились.

Военный министр Сухомлинов считал, что Унтербергер искусственно нагнетал панику для ускорения работ по усилению обороны Владивостока, Николай II придерживался мнения, что Унтербергер пал жертвой самовнушения, вызванного нехваткой актуальной информации о состоянии российско-японских отношений $[4$, с. 362]. Желание выяснить причины негативного отношения Унтербергера к Японии, оценить правдивость его опасений о скором начале войны между Санкт-Петербургом и Токио, а также обвинения в том, что министерство финансов не обеспечивает в достаточной мере финансирование строительства Владивостокской крепости послужили причинами, по которым Николай II отправил Коковцова с поездкой по русскому Дальнему Востоку, в рамках которой он должен был посетить Харбин, Владивосток и Хабаровск [4, с. 369].

Приехав во Владивосток, Коковцов столкнулся с предвзятым отношением к себе со стороны генерал-губернатора Унтербергера, который, по мнению Коковцова, убедил себя в опасности со стороны Японии, равно как и в том, что именно министр финансов виновен в недостаточном финансировании Владивостокской крепости. Проведённая Коковцовым проверка во Владивостоке позволила составить список неиспользованных строителями крепости кредитов [4, с. 401]. Здесь же Коковцов столкнулся с плохо скрываемым скептицизмом местных офицеров. Возглавлявший инженеров крепости Вацлав Жигалковский прямо заявлял Коковцову, что Редигер был прав, требуя ликвидации крепости, своевременно строительные работы на объектах никогда не начнутся, а военные инженеры крепости лишь даром получают свои деньги [4, c. 402].

По итогам поездки Коковцова телеграммы Унтербергера о беззащитности Дальнего Востока и японской угрозе прекратились [4, с. 402]. В том же 1909 г., после того как Коковцов представил доклад о поездке и отдельный о состоянии Владивостокской крепости, Николай II одобрил общий проект усиления Владивостокской крепости, сделал выговор военному министру Сухомлинову за медлительность и приказал привести крепость в надлежащее состояние [1, с. 203]. Именно после этого началось строительство Третьей линии 
обороны Владивостока, включавшей в себя новые фрорты, батареи, капониры, пороховые погреба и иные сооружения Владивостокской крепости.

Если среди высших чинов имперской администрации существовали разные взгляды на Дальний Восток и необходимость повышения его обороноспособности, то среди руководства Приамурского генерал-губернаторства точка зрения на эту проблему была единой и монолитной. В то время, пока в Петербурге обсуждалось будущее Владивостокской крепости, дальневосточная администрация активно доказывала необходимость сохранения и укрепления Дальнего Востока [8, с. 451].

Автор телеграмм, встревоживших представителей высшей власти России, генерал-губернатор Приамурья П.Ф. Унтербергер был сторонником ограничения миграции китайцев и корейцев. Он видел задачу властей в том, чтобы "как можно скорей создать на Дальнем Востоке крепкий, однородный и дружный славянский оплот против могущих быть выступлений желтой расы", заявляя, что сорокалетний опыт ассимиляции корейцев дал отрицательные результаты, а их изоляционизм делает невозможным интеграцию среди славянского населения края [10, с. 83].

При этом Унтербергер считал, что глобальная задача Дальнего Востока сводится к тому, чтобы принимать переизбыток населения из европейской части России, предоставлять доступ к морским коммуникациям для сибирских купцов и товаров. Ради достижения этих целей, считал приамурский генерал-губернатор, необходимо придерживаться политики регионального изоляционизма, добиться мира на границах региона, чтобы исключить влияние соседей на его развитие [10, с. 426].

Можно было бы предположить, что подобные взгляды не были политикой местной администрации, а лишь политикой одного человека. Однако преемник Унтербергера на посту приамурского генерал-губернатора Н.Л. Гондатти продолжал в том же духе, требуя ввести новые запретительные меры по отношению к китайцам и корейцам. Политика Унтербергера-Гондатти совпадала по духу со столыпинской национальной и переселенческой политикой, опиравшейся на русский национализм [8, с. 462]. Возглавляя Тобольскую губернию потомок итальянских переселенцев Гондатти составил 20-страничную программу развития дальневосточного региона, провозглашая в духе столыпинской национальной политики тезис о том, что "Дальний Восток должен быть русским и только для русских" [8, с. 451-452], и став главой Приамурья он старался этого тезиса придерживаться.

Местная дальневосточная администрация считала самым действенным способом сохранения региона в составе России ускорение русской переселенческой колонизации, с параллельным ограничением переселения китайцев и корейцев. Одновременно с этим руководители Приамурья опасались войны с Японией, полагая, что Дальний Восток недостаточно укреплён, в том числе и по вине медлительности и неповоротливости столичной бюрократии. Эти взгляды, которые можно охарактеризовать как оборонически-тревожные, требовали скорейшего воплощения принщипа защищённости региона в виде конкретных сооружений. Наиболее полно идею защищённости Дальнего Востока могла воплотить Владивостокская крепость, поэтому нет ничего странного в том, что П.Ф. Унтербергер был так заинтересован в скорейшем её усилении. Сам он был военным инженером и впервые оказался во Владивостоке именно для выполнения приказа по созданию оборонительных сооружений в городе. Его сын Павел Петрович также был военным инженером, работавшим над созданием сооружений Владивостокской крепости, в частности, ему принадлежит проект Форта № 2. [2, с. 435].

После того, как нами были рассмотрены взгляды имперской и дальневосточной администрации, оценивающие Дальний Восток и его место в составе России, стоит перейти к тому, какого мнения по этому поводу придерживалось руководство Владивостокской крепости. Несмотря на то, что оно стояло в самом низу этой властной пирамиды, его действия также оказывали влияние на развитие этого комплекса фрортификационных сооружений.

Важную роль в развитии крепости, усилении её боеспособности и строительстве сыграл генерал-лейтенант Владимир Александрович Ирман, занимавший эту должность в 1906-1912 гг. [1, с. 301]. Уроженец Киевской губернии, немец по национальности и дворянин по происхождению, Ирман был 
глубоко православным патриотом и идейным монархистом [1, с. 301]. Его карьера была неразрывно связана с армией: 1-я Московская военная гимназия, 3-е Александровское военное училище в Москве, после его окончания служба в артиллерии [1, с. 301]. В 1900 г. Ирман прибывает на Дальний Восток как командир 1-го дивизиона 2-й Гренадёрской артиллерийской бригады, участвует в Китайском походе 1900-1901 г., принимает участие в Русско-японской войне, где оказывается в японском плену. После освобождения из плена в 1906 г. Ирман приезжает во Владивосток и возглавляет Владивостокскую крепость сначала как исполняющий должность, а потом как полноценный комендант.

За время руководства Владивостокской крепостью Владимиру Ирману удалось разрешить многие насущные вопросы, связанные с бытом солдат и офицеров гарнизона, изменить дисциплину солдат в лучшую сторону и преодолеть революционные события 1905-1907 г. [1, с. 306]. Помимо текущих проблем крепости, Владимир Ирман уделял немалое внимание её будущему - именно из-под пера Ирмана в июне 1910 г. вышел доклад на имя главного руководителя работами по усилению Владивостокской крепости инженер-генералу Вернандеру, посвящённый вопросу наименования объектов Владивостокской крепости (РГВИА. Ф. 802. Оп. 5. Д. 16793. Л. 383-385).

Данный доклад интересен как артефакт истории намерений Ирмана по превращению Владивостокской крепости не только в важный военно-фрортификационный объект, но и идеологическое явление, которое должно было закрепить в сознании гарнизона крепости и населения Владивостока фоакт принадлежности этих территорий России.

В самом начале доклада Ирман отмечает, что в связи с учреждением нового плана строительства Владивостокской крепости, возникает насущная необходимость в систематическом наименовании объектов крепости с целью того, чтобы устранить путаницу в названиях и создать условия при которых "даже малоразвитый телефонист или нижний чин, сразу, по названию или номеру определял бы местонахождение искомого форта, опорного пункта, батареи и проч." (РГВИА. Ф. 802. Оп. 5. Д. 16793. Л. 383). Но в то же время, как отмечал автор доклада "названия фортов, опорных пунктов, батарей, должны будить в сердцах воинов патриотизм, самоотверженные воинские чувства, жажду победы, чтобы не быть хуже предков" (РГВИА. Ф. 802. Оп. 5. Д. 16793. Л. 383).

Будучи сторонником той точки зрения, что "Владивосток - оплот русской власти и русской жизни на восточной границе России, которая в течении веков непрерывно расширялась и ныне дошла до естественной своей границы на берегах великого океана, и потому все названия должны быть русско-историческими, лучше всего говорящими даже простому солдату об государственной важности высочайше вверенного нашей охране восточно-пограничного оплота России" (РГВИА. Ф. 802. Оп. 5. Д. 16793. Л. 383), Ирман предлагал следующий проект переименования объектов Владивостокской крепости: форты № № 1-7 главной линии Северного сухопутного оборонительного обвода на полуострове Муравьёва-Амурского переименовать в честь представителей правящей династии Романовых (РГВИА. Ф. 802. Оп. 5. Д. 16793. Л. 383), Форту № 8 присвоить имя Троицко-Сергиевского, в честь осады Троицко-Сергиевской лавры во время событий Смутного времени (РГВИА. Ф. 802. Оп. 5. Д. 16793. Л. 384), а фрорты Южного оборонительного обвода на острове Русском назвать в честь представителей династии Рюриковичей (РГВИА. Ф. 802. Оп. 5. Д. 16793. Л. 384). Расположенные на полуострове Муравьёва-Амурского форты второй (цитадельной) линии Северного сухопутного оборонительного обвода, названные в честь Муравьёва-Амурского, Линевича и Суворова должны были сохранить свои прежние наименования (РГВИА. Ф. 802. Оп. 5. Д. 16793. Л. 384).

Опорные пункты главной линии Ирман предлагал переименовать в честь "исторически выдаюшихся, непременно уже умерших, во избежание игры в тщеславие генералов русской армии" (РГВИА. Ф. 802. Оп. 5. Д. 16793. Л. 384). Береговые батареи предполагалось переименовать "по названиям полей сражений, арены побед русской армии" (РГВИА. Ф. 802. Оп. 5. Д. 16793. Л. 384), а опорные пункты на острове Русском должны были получить имена генерал-адъютанта Скобелева и героя Русско-японской во- 
йны генерал-лейтенанта Кондратенко (РГВИА. Ф. 802. Оп. 5. Д. 16793. Л. 384). Как считал Ирман, подобная система наименований "заставит гарнизон жить в мире славного прошлого русских войск, что естественно должно отразиться возвышающим дух влиянием на поступки настоящего" (РГВИА. Ф. 802. Оп. 5. Д. 16793. Л. 385).

На первый взгляд, может показаться, что проект генерал-лейтенанта Ирмана носил сугубо политико-воспитательный характер и его задача заключалась в том, чтобы укрепить боевой дух и дисциплину крепостного гарнизона. Но вместе с тем в докладе коменданта Владивостокской крепости отчётливо заметен ещё один, русификаторский смысловой слой: в рамках своего доклада Ирман писал, что "необходимо омывающую фрронт передовых позиций у высоты 183 (где проектируется Троицко-сергиевский форт), речку Лянчихе русским именем, например речкой Полтавкой, и омывающую фрронт крепостного региона с восточной стороны и также фронт Майхинских дальних передовых позиций крепости реку Майхе - например речкой Рымник (победа Суворова)" (РГВИА. Ф. 802. ОП. 5. Д. 16793. Л. 385). Ирман считал, что "славные русские наименования, стерев из памяти китайщину, закрепят в сознании защитников, что эта кровная русская земля" (РГВИА. Ф. 802. Оп. 5. Д. 16793. Л. 385). По иронии судьбы, данные предложения Ирмана относились к вопросу наименования так и не построенного Форта № 8, который не был даже спроектирован и включён в проект 1910 г. по строительству новых объектов Владивостокской крепости [1, с. 203-204].

Начальник штаба Владивостокской крепости барон Алексей Будберг в своих воспоминаниях писал, что по мнению Ирмана "его комендантские обязанности сводились к точному и беспрекословному исполнению всего того, что приказывалось или указывалось ему свыше" [3, с. 389]. Такая своеобразная оценка способностей коменданта крепости вполне укладывается в общий ход типичных будберговских рассуждений: начальник штаба крепости был достаточно пессимистично настроен к проекту сооружения Владивостокской крепости 1910 г., считая его неполноценным и не удовлетворяющим нуждам обороны города [3, с. 391-392]. Нельзя забывать, что критический настрой Будберга к проектам развития крепости в итоге стал причиной, по которой он был лишён права выражать особые мнения на решения Крепостного Строительного Комитета [3, с. 394]. Так что нельзя исключать того, что мнение Будберга о том, что "генерал Ирман был полнейшим профаном в крепостном деле, им совершенно не интересовался, утверждал и поддерживал всё, что ему указывал генерал Вернандер или докладывал строитель крепости" [3, с. 394] неоправданно преувеличивало степень несамостоятельности Ирмана в вопросах развития и усовершенствования Владивостокской крепости.

Но даже если предположить, что это мнение Будберга преувеличено, то всё равно выходит, что особой самостоятельности в вопросах, связанных с дальнейшим развитием крепости, Ирман не проявлял и на этом фоне его проект о присвоении новых названий укреплениям крепости и переименовании географических объектов, с чётким и подробным обоснованием данных действий, не может не вызвать любопытства. Особенно в части причин, по которым этот проект возник.

К началу XX в. Сибирь, частью которой тогда считался Дальний Восток, считалась регионом, который надо спешно "присоединить" к России, создать условия, в рамках которых будет господствовать осознание того, что, цитируя проект Ирмана, это "кровная русская земля". Одним из способов такого "присоединения" можно было бы назвать создание локальных центров имперского влияния [7, с. 172]. Одним из таких центров мог считаться Владивосток, ставший, подобно Омску, Оренбургу или Ташкенту, одним из окон России в Азию [7, с. 173]. Владивостокская крепость оказывалась локальным центром имперской власти внутри локального центра имперской власти - главный руководитель работ по усилению Владивостокской крепости инженер-генерал Вернандер имел необычайно широкие полномочия, связанные с важностью поставленной перед ним задачи, и даже имел право принимать те решения, которые при проектировании предыдущих линий обороны крепости возлагались на российского императора $[1, \mathbf{c .} 203]$. Как уже было рассмотрено выше, вопрос о сохранении и совершенствовании Владивостокской крепости рассма- 
тривался на высшем уровне как один из ключевых, ответ на который мог дать ответ на вопрос о будущем Дальнего Востока в составе Российской империи.

Проект генерал-лейтенанта Ирмана по присвоению наименований объектам Владивостокской крепости можно считать одним из шагов по русификации региона. Целью этой политики, проводимой имперскими властями, всегда было приведение окраин к некоей общей унифиццированной модели, согласно которой должны были выглядеть регионы империи. Для русификации Дальнего Востока и Сибири было характерно то, что эти территории изначально осмыслялись как чуждая территориия, превратившаяся в колонии [5, с. 74]. Представление о том, что эти окраины являются русской землёй, а не инонациональным регионом, подобно Польше, Кавказу или Финляндии, возникло лишь к началу XX в. [5, с. 75]. До Русско-японской войны часть имперских элит находилась под воздействием представлений о жёлтой угрозе, исходящей от стран Азии, приверженцем которых был, например, военный министр Куропаткин [9, с. 139]. Сторонники данной точки зрения считали, что российская экспансия на Дальнем Востоке должна зайти как можно дальше вглубь региона, чтобы отвести от восточных границ России возможную военную угрозу со стороны Китая, Кореи или Японии. Другая часть элиты, которую олицетворял министр финансов Сергей Витте, считала, что российский капитализм должен расширять сферу своего влияния именно за счёт дальневосточных стран, так как только в таких странах он и может быть успешен [9, с. 105-106]. В условиях, когда первоочередной задачей для имперской политики было продвижение российского влияния вглубь Азии, вне зависимости от своей мотивации вопросы идеологического "присоединения" уже существующих российских владений на Дальнем Востоке отходили на второй план. Поражение в Русско-японской войне привело не только к осознанию того, что на смену экспансии пришла пора удержания и русификации оставшихся дальневосточных земель, дабы они не были утеряны. Стоит отметить, что русификация была не каким-то единым процессом, а принимала облик нескольких разных процессов [5, с. 54-55]. К этим процессам могли относиться административная и миссионерская деятельность, этническая ассимиляция и принятие норм русской культуры, и каждый из этих процессов реализовывался в тех или иных регионах империи сообразно их специфрике [5, c. 58-59].

Проект Ирмана в итоге так и не был принят. Авторы многотомника, посвящённого истории Владивостокской крепости, сравнивают его с осуществлённым проектом переименования топонимов Владивостока и Приморья, который последовал после обострения советско-китайских отношений в 1970-е гг. [1, с. 222]. При этом причины, по которым проект В.А. Ирмана не был принят не указываются, отмечается лишь то, что "здравый смысл победил и эти географические переименования не состоялись", хотя отмечается, что предложенные Ирманом названия вошли в обиход, пусть и не были закреплены в документах [1, с. 222]. Обстоятельства из-за которых проект коменданта Владивостокской крепости не был принят вызывают безусловный исследовательский интерес, но так как для их прояснения необходима вдумчивая и долгая работа с архивными материалами, в первую очередь, Российского государственного военно-исторического архива в Москве, то они могут служить темой для отдельного исследования по этому вопросу.

Проект Ирмана можно назвать актом административной русификации региона: используя свою власть коменданта крепости, он хотел закрепить в названии её объектов определённый идеологический набор из фрактов и персон русской истории, который бы постоянно транслировался в умы гарнизона крепости и местных жителей. Этот конструкт был собран для того, чтобы "привязать" Приморье к России через некоторые общие для всей страны исторические и идеологические представления, связанные с теми или иными эпохами. Иными словами, цель проекта Владимира Александровича Ирмана заключалась в том, чтобы вписать Владивосток в общую государственную историю России и показать, что дальневосточный регион, который символизировала Владивостокская крепость, неразрывно связан с Российской империей на идейном уровне. Отсюда можно сделать вывод, что одной из целей существования крепости он считал не только фризическую, но и идейную защиту Приморья, превращение Владивостокской крепости в один из локальных цен- 
тров имперской власти, который показывал бы, что на этой земле российская власть остаётся навсегда и что здесь невозможно повторение событий продажи Аляски или падения Порт-Артура.

Это соответствовало желанию Санкт-Петербурга удержать регион в составе империи и, одновременно с тем, укладывался в националистическую политику местной администрации, стремившейся сделать из региона "славянский бастион в Азии". Интересно, что автор проекта был включён в обе системы власти: как комендант Владивостокской крепости он подчинялся командующему Приамурским военным округом, коим был генерал-губернатор Унтербергер, и военному министру Российской империи единовременно. Данный фракт может символизировать, что именно в фигуре Ирмана переплелись общеимперские и региональные политические устремления по обустройству Дальнего Востока и Владивостокской крепости, а может быть лишь совпадением.

\section{Литература}

1. Авилов Р.С., Аюшин Н.Б., Калинин В.И. Владивостокская крепость: войска, фортификация, события, люди. Часть II. Уроки Порт-Артура. 1906-1917 гг. /Р.С. Авилов, Н.Б. Аюшин, В.И. Калинин. Владивосток: Дальнаука, 2014. 408 с.

2. Авилов Р.С., Аюшин Н.Б., Калинин В.И. Владивостокская крепость : войска, фортификация, события, люди. Часть III. "Крепость трёх измерений". / Р.С. Авилов, Н.Б. Аюшин, В.И. Калинин. Владивосток: Дальнаука, 2016. 518 с.

3. Будберг А.П., барон. Сибирские воспоминания /Ред.-сост., комментарий Р.С. Авилов, В.И. Калинин; вступ. ст. Р.С. Авилов, Н.Б. Аюшин, В.И. Калинин. / А.П. Будберг. Владивосток: Общество изучения Амурского края. Приморское краевое отделение Русского географического общества, 2017. 434 с.

4. Коковцов В.Н. Из моего прошлого. Воспоминания 1903-1919.: в 2 кн. / В.Н. Коковцов. Париж : Изд. журн. Иллюстрированная Россия, 1933. 504+504 с.

5. Миллер А.И. Империя Романовых и национализм: эссе по методологии исторического исследования. /А.И. Миллер. М.: Новое литературное обозрение, 2006. 248 с.

6. Редигер А.Ф. История моей жизни. Воспоминания военного министра.: в 2 кн. / А.Ф. Редигер. М.: Канон-Пресс-Ц, Кучково поле, 1999. 576+528 с.

7. Ремнёв А.В. Границы и центры Сибири / А.В. Ремнёв / Российская империя в сравнительной перспективе. Сборник статей. М.: "Новое издательство", 2004. С. 168173.

8. Ремнёв А.В. Россия Дальнего Востока. Имперская география власти XIX - начала XX веков. / А.В. Ремнёв. Омск: Изд-во Омск. гос. ун-та, 2004. 552 с.

9. Схиммельпеннинкван дер Ойе Д. Навстречу Восходящему солнцу . Как имперское мифротворчество привело Россию к войне с Японией. /Д. Схиммельпенникван дер Ойё. М.: Новое литературное обозрение, 2009. 421 с.

10. Унтербергер П.Ф. Приамурский край. 1906-1910 гг. /П.Ф. Унтербергер. СПб.: 1912. 428 c.

\section{Транслитерация по ГОСТ 7.79-2000 Система Б}

1. Avilov R.S., Ayushin N.B., Kalinin V.I. Vladivostokskaya krepost': vojska, fortifikatsiya, sobytiya, lyudi. CHast' II. Uroki Port-Artura. 1906-1917 gg. /R.S. Avilov, N.B. Ayushin, V.I. Kalinin. Vladivostok: Dal'nauka, 2014. 408 s.

2. Avilov R.S., Ayushin N.B., Kalinin V.I. Vladivostokskaya krepost' : vojska, fortifikatsiya, sobytiya, lyudi. CHast' IIII. "Krepost' tryokh izmerenij". / R.S. Avilov, N.B. Ayushin, V.I. Kalinin. Vladivostok: Dal'nauka, 2016. 518 s.

3. Budberg A.P., baron. Sibirskie vospominaniya /Red.-sost., kommentarij R.S. Avilov, V.I. Kalinin; vstup. st. R.S. Avilov, N.B. Ayushin, V.I. Kalinin. / A.P. Budberg. Vladivostok: Obshhestvo izucheniya Amurskogo kraya. Primorskoe kraevoe otdelenie Russkogo geograficheskogo obshhestva, 2017. $434 \mathrm{~s}$.

4. Kokovtsov V.N. Iz moego proshlogo. Vospominaniya 1903-1919.: v 2 kn. / V.N. Kokovtsov. Parizh : Izd. zhurn. Illyustrirovannaya Rossiya, 1933. 504+504 s.

5. Miller A.I. Imperiya Romanovykh i natsionalizm: ehsse po metodologii istoricheskogo issledovaniya. /A.I. Miller. M.: Novoe literaturnoe obozrenie, 2006. 248 s.

6. Rediger A.F. Istoriya moej zhizni. Vospominaniya voennogo ministra.: v 2 kn. / A.F. Rediger. M.: Kanon-Press-TS, Kuchkovo pole, 1999. 576+528 s.

7. Remnyov A.V. Granitsy i tsentry Sibiri / A.V. Remnyov / Rossijskaya imperiya v sravnitel'noj perspektive. Sbornik statej. M.: "Novoe izdatel'stvo", 2004. S. 168-173. 
8. Remnyov A.V. Rossiya Dal'nego Vostoka. Imperskaya geografiya vlasti XIX - nachala XX vekov. / A.V. Remnyov. Omsk: Izd-vo Omsk. gos. un-ta, 2004. 552 s.

9. Skhimmel'penninkvan der Oje D. Navstrechu Voskhodyashhemu solntsu. Kak imperskoe mifotvorchestvo privelo Rossiyu k vojne s YAponiej. /D. Skhimmel'pennikvan der Ojyo. M.: Novoe literaturnoe obozrenie, 2009. 421 s. $428 \mathrm{~s}$.

10. Unterberger P.F. Priamurskij kraj. 1906-1910 gg. /P.F. Unterberger. SPb.: 1912.

Азаревич В. К. Проект В.А. Ирмана по переименованию объектов Владивостокской крепости как попытка русификации Дальнего Востока.

В статье на основе мемуаров и исследований, а также материалов Российского государственного военно-исторического архива рассматривается проект коменданта Владивостокской крепости В.А. Ирмана по переименованию объектов крепости в контексте представлений российских правящих элит о будущем Дальнего Востока и методах символического закрепления региона в составе России. Показаны точки зрения на необходимость сохранения и будущее Владивостокской крепости, существовавшие у руководства страны и Дальнего Востока. Рассмотрены намерения и цели В.А. Ирмана, согласно его проекту. В заключении к статье представлен обобщающий вывод о намерениях В.А. Ирмана по русификации региона при помощи Владивостокской крепости. Показано, что проект укладывался в общее русло настроений имперской и региональной элит.

Ключевые слова: Дальний Восток, Владивосток, Владивостокская крепость, В.А. Ирман, Российская империя, русификация, В.Н. Коковиов, П.Ф. Унтербергер, имперская история

Azarevich V.K. V.A. Irman's project of renaming the facilities of Vladivostok fortress as an attempt of Russification of the Far East.

Based on memoirs and studies, as well as materials from the Russian State Military Historical Archive, the article focuses on the commandant V.A. Irman's project of renaming the facilities of the Vladivostok fortress within the context of the ideas of the Russian ruling elites about the future of the Far East and methods of symbolic consolidation of the region within Russia. It is shown how the views on the role of the Vladivostok fortress differed among the imperial elites and the local leadership. The conclusion establishes the intentions of V.A. Irman on the Russification of the region with the help of the Vladivostok Fortress. It is shown that the project fit into the general thrust of the sentiments of the imperial and regional elites.

Key words: Far East, Vladivostok, Vladivostok fortress, V.A. Irman, Russian Empire, Russification, V.N. Kokovtsov, P.F. Unterberger, Imperial History

Для цитирования: Азаревич В. К. Проект В.А. Ирмана по переименованию объектов Владивостокской крепости как попытка русификации Дальнего Востока // Ойкумена. Регионоведческие исследования. 2021. № 2. C. 7-15. DOI: 10.24866/1998-6785/2021-2/7-15

For citation: Azarevich V. K. V.A. Irman's project of renaming the facilities of Vladivostok fortress as an attempt of Russification of the Far East // Ojkumena. Regional researches. 2021. № 2.

P. 7-15. DOI: 10.24866/1998-6785/2021-2/7-15 